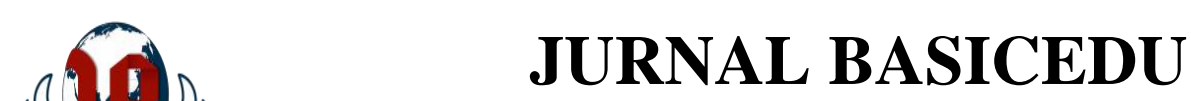

Volume 5 Nomor 5 Tahun 2021 Halaman 3299 - 3305

Research \& Learning in Elementary Education

https://jbasic.org/index.php/basicedu

PNIVERSITAS

hips:/jbasic.org/index.php/basicedu

\title{
Pemanfaatan Aplikasi Google Classroom dalam Meningkatkan Efektivitas Belajar Mahasiswa Berbasis Daring di Masa Pandemik Covid-19
}

\author{
Juliaster Marbun ${ }^{1}$, Samuel Juliardi Sinaga ${ }^{2}$
}

Fakultas Keguruan dan Ilmu Pendidikan, Universitas HKBP Nommensen Medan, Indonesia ${ }^{1,2}$

E-mail: juliaster.marbun@uhn.ac.id ${ }^{1}$, samuel.sinaga@uhn.ac.id ${ }^{2}$

\begin{abstract}
Abstrak
Akibat dari pandemik covid-19 membuat sistem belajar dari berbasis konvensional menjadi berbasis daring. Google Classroom menjadi salah satu aplikasi khusus yang digunakan untuk pembelajaran daring yang dapat dilakukan dari jarak jauh sehingga memudahkan dosen dan mahasiswa untuk membuat, mengelompokan dan membagikan tugas, selain itu dosen dan mahasiswa bisa setiap saat melakukan kegiatan pembelajaran melalui ruang kelas Google Classroom. Tujuan dari penelitian ini adalah untuk mengetahui efektivitas belajar dari mahasiswa FKIP UHN dalam mengikuti sistem belajar berbasis daring melalui aplikasi Google Classroom. Hasil penelitian menunjukkan bahwa mayoritas mahasiswa yang belajar melalui aplikasi belajar Google classroom dapat meningkatkan efektivitas belajarnya yaitu mempermudah dalam mengerjakan tugas, terampil menggunakan sarana teknologi dan informasi dan bisa dengan cepat mengetahui hasil belajarnya.
\end{abstract}

Kata kunci : Covid-19, Google classroom, Efektivitas, Belajar Daring.

Abstract

Pandemic Covid-19 effect, the learning system from conventional to online based, Google classroom is one of special applications for online learning that can be done remotely, making it easier for lecturers and students to create, group and distribute assignments, besides that lecturers and students to create, group and distribute assignments, beside that lecturers and students can carry out learning activities at any time through the google classroom. The purpose of this study was to determine the learning effectiveness of FKIP UHN students in participating in an online-based learning system through the Google Classroom application. The result showed that the majority of students who studied through the Goggle classroom learning application could improve their effectiveness, namely making it easier to do assignments, being skilled at using technology and information facilities and information facilities and being able to quickly find out their learning outcomes.

Keywords: Covid-19, Google classroom, effectiveness, study online.

Copyright (c) 2021 Juliaster Marbun, Samuel Juliardi Sinaga

Corresponding author :

Email : juliaster.marbun@uhn.ac.id

DOI : https://doi.org/10.31004/basicedu.v5i5.1326

ISSN 2580-3735 (Media Cetak)

ISSN 2580-1147 (Media Online)

Jurnal Basicedu Vol 5 No 5 Tahun 2021

p-ISSN 2580-3735 e-ISSN 2580-1147 
3300 Pemanfaatan Aplikasi Google Classroom dalam Meningkatkan Efektivitas Belajar Mahasiswa Berbasis Daring di Masa Pandemik Covid-19 - Juliaster Marbun, Samuel Juliardi Sinaga

DOI: https://doi.org/10.31004/basicedu.v5i5.1326

\section{PENDAHULUAN}

Pandemi Covid-19 telah membuat tatanan dunia menjadi berubah. Banyak korban akibat dari ganasnya virus ini membuat seluruh dunia menjadi terganggu. Dampak yang ditimbulkan akibat merebaknya virus ini adalah pembatasan kegiatan atau aktivitas manusia demi menekan laju penyebaran virus. Indonesia menjadi salah satu negara yang merasakan dampaknya. Melihat keadaan Indonesia saat ini, yang merupakan Negara dengan kasus covid19 terbanyak di Asia Tenggara. Sejak bulan Maret 2020 secara nasional kegiatan belajar siswa di lakukan di rumah di karenakan semakin meningkat per 15 Juli 2021 sudah mencapai 2.726 .803 kasus. Hal ini tentu saja sangat menghawatirkan.

Berbagai kebijakan telah dikeluarkan oleh pemerintah Indonesia untuk mengurangi tingkat penyebaran virus corona dengan melakukan inovasi baru baik dalam bidang ekonomi, sosial, pendidikan, kesehatan dan keamanan. Diantara upaya tersebut dengan cara pemerintah mewajibkan masyarakat untuk WFH (work from home), SFH (study from home), sosial distancing, physical distancing, Pemberlakuan Pembatasan Sosial Berskala Besar (PSBB), hingga program terbaru Perberlakukan Pembatasan Kegiatan Masyarakat (PPKM). Tujuan dari Kebijakan-kebijakan yang dikeluarkan untuk membatasi penyebaran COVID-19 berdampak pada berbagai bidang diseluruh dunia khususnya pendidikan di Indonesia (Herliandry et al., 2020).

Pada masa pandemik sekarang semua institusi pendidikan diminta untuk melakukan pencegahan penyebaran Covid-19, WHO merekomendasikan untuk menghentikan sementara kegiatan-kegiatan yang berpotensi menimbulkan kerumunan massa. Untuk itu pembelajaran konvensional yang mengumpulkan banyak siswa dalam satu ruangan perlu ditinjau ulang pelaksanaannya (Siahaan et al., 2021). Pembelajaran harus dilaksanakan dengan skenario yang mampu meminimalisir kontak fisik antara siswa dengan siswa lain, ataupun antara siswa dengan dosen dan penggunaan teknologi digital memungkinkan siswa dan guru berada di tempat yang berbeda selama proses pembelajaran (Milman, N. B., 2015).

Kementrian pendidikan dibawah kepemimpinan Menteri Pendidikan Nadiem Makarim, melakukan langkah tepat dengan menetapkan bahwa proses pembelajaran dilakukan jarak jauh atau dikenal dengan sebutan belajar daring. Tidak hanya di Indonesia saja yang melakukan pembelajaran jarak jauh (daring), akan tetapi seluruh dunia sedang menerapkan sistem pembelajaran tersebut. Dalam keadaan normal pun banyak terjadinya tumpang tindih dalam pembelajaran di berbagai daerah. Sesuai petunjuk Menteri Pendidikan dan Kebudayaan Republik Indonesia menerbitkan Surat Edaran No. 4 Tahun 2020 tentang pelaksanaan kebijakan pendidikan dalam masa darurat penyebaran Covid-19 yang dikeluarkan pada 2 tanggal 24 Maret 2020.

Pembelajaran berbasis daring didefinisikan sebagai pengalaman transfer pengetahuan menggunakan video, audio, gambar, komunikasi teks, perangkat lunak (Basilaia \& Kvavadze, 2020) dan menggunakan jaringan internet dengan aksesibilitas, konektivitas, fleksibilitas dan kemampuan untuk memunculkan berbagai jenis interaksi pembelajaran. (Firman dan Rahayu, 2020). Dalam pelaksanaan pembelajaran daring membutuhkan dukungan perangkat-perangkat mobile seperti telepon pintar, tablet dan laptop yang dapat digunakan untuk mengakses informasi dimana saja dan kapan saja.

Seperti yang telah dijalankan saat ini, pembelajaran dilakukan secara daring atau dari rumah untuk seluruh pelajar dan mahasiswa karena adanya pembatasan sosial sebagai upaya untuk mengatasi atau setidaknya memperkecil angka penyebaran virus corona yang semakin hari semakin meningkat. Dengan adanya pembelajaran berbasis daring maka Dosen,Guru, mahasiswa dan siswa harus bisa menggunakan dan memanfaatkan teknologi untuk melangsungkan kegiatan pembelajaran setiap harinya sebagai solusi dalam belajar di era pandemic covid-19.

Universitas HKBP Nommensen juga ikut menerapkan sistem pembelajaran berbasis daring sesuai dengan instruksi menteri pendidikan dan kebudayaan. Aplikasi yang dapat mendukung pelaksanaan pembelajaran berbasis daring antara lain melalui berbagai aplikasi seperti google classrom, zoom meeting, 
3301 Pemanfaatan Aplikasi Google Classroom dalam Meningkatkan Efektivitas Belajar Mahasiswa Berbasis Daring di Masa Pandemik Covid-19 - Juliaster Marbun, Samuel Juliardi Sinaga

DOI: https://doi.org/10.31004/basicedu.v5i5.1326

whatsaap, kelas cerdas, zenius, quipper dan microsoft. Selama masa pandemi Covid-19 pelaksanaan pembelajaran dilakukan dirumah atau online menjadi solusi terbaik (Dewi,2020).

Salah satu media pembelajaran daring yang saat ini sedang digunakan di Universitas HKBP Nommensen Medan adalah Google Classroom. Google Classroom adalah aplikasi khusus yang digunakan untuk pembelajaran daring yang dapat dilakukan dari jarak jauh sehingga memudahkan dosen dan mahasiswa untuk membuat, mengelompokan dan membagikan tugas, selain itu dosen dan mahasiswa bisa setiap saat melakukan kegiatan pembelajaran melalui ruang kelas Google Classroom (Ananda et al., 2021). Penggunaan aplikasi ini sangat membantu mahasiswa dalam belajar, menyimak, membaca dan mengirim tugas dari jarak jauh.

Untuk menggunakan Google Classroom, dosen dan mahasiswa dapat mengakses aplikasi ini dengan menggunakan dua cara, yaitu website dan aplikasi. Untuk website dapat diakses menggunakan browser apapun seperti Chrome, FireFox, ataupun Internet Explorer. Sedangkan untuk aplikasi dapat diunduh secara gratis melalui Playstore untuk Android dan App Store untuk iOS. Pada dasarnya pemanfaatan aplikasi Google Classroom mempunyai kelebihan salah satunya dalam penggunaan Google Classroom dapat mengirimkan tugas berbentuk dokumen, photo, dan video pembelajaran kepada mahasiswa yang berkaitan dengan materi mata kuliah yang sedang berlangsung selama satu semester.

Aplikasi ini juga membantu dosen dalam Melakukan setiap penilaian dari tugas apa yang telah diberikan oleh dosen kepada mahasiswa, interaksi yang lancar antara dosen dan mahasiswa didalam kolom komentar, mahasiswa juga bisa melakukan absen setiap pembelajaran dimulai, dan mahasiswa mengirimkan tugas yang telah selesai dilaksanakan dan itupun nanti tersimpan di Google Drive dan tersusun rapi sehingga sistem belajar dan penilaian terintegrasi dengan baik serta sistematis. Hal ini dapat dijadikan sebagai media dalam pembelajaran berbasis Daring, karena Google Classroom memiliki berbagai kelebihan dalam menciptakan pembelajaran yang mudah untuk digunakan siapaun penggunanaya dan untuk pengiriman tugastugas menjadi sistematis.

Dalam penelitian sebelumnya dengan topik Google Classroom: What works and How? Menyertakan Google Kelas membantu memantau pembelajaran siswa ,pengajar dapat melihat semua aktivitas belajar siswa dalam proses pembelajaran. Interaksi antara guru dan siswa terekam dengan baik (Shampa Iftakhar, 2016). Google Classroom telah mendukung kesuksesan dalam belajar mengajar karena dapat diintegrasikan dengan berbagai model atau metode (Henukh et al., 2020). Sehingga melalui Google Classroom, diasumsikan bahwa tujuan pembelajaran akan lebih mudah terwujud dan penuh makna (Hanifah \& Putri, 2020). penggunaan Google Classroom selama pandemi efektif dan bermanfaat untuk meningkatkan keterampilan, kedisiplinan siswa, serta memenuhi tuntutan pemerintah untuk terus melanjutkan proses belajar mengajar (Okmawati, 2020). Pelaksanaan penggunaan Google Classroom dalam proses pembelajaran Daring di berbagai institusi pendidikan semakin mempermudah proses pembelajaran berbasis daring.

Berdasarkan studi dan kajian literatur diatas yang menyatakan Google Classroom efektif dalam meningkatkan kegiatan belajar mengajar, maka peneliti melakukan penelitian untuk mengetahui pemanfaatan Google Classroom dalam pembelajaran berbasis daring selama pandemi Covid-19 dalam meningkatkan efektivitas belajar mahasiswa pada mahasiswa FKIP UHN Medan.

\section{METODE PENELITIAN}

Penelitian ini dilakukan dengan menggunakan penelitian kualitatif deskriptif. Pengumpulan data dilakukan studi literatur dari penelitian terdahulu, wawancara secara daring dan kuesioner daring berupa tautan link Google Form yang dibagikan kepada mahasiswa melalui WA grup. Kuesioner disusun menurut skala Likert yang terdiri dari 20 pertanyaan dengan empat alternatif jawaban, yaitu sangat tidak setuju (1) Tidak setuju (2), Setuju (3), sangat setuju (4). Sementara teknik analisis data yang digunakan adalah 
3302 Pemanfaatan Aplikasi Google Classroom dalam Meningkatkan Efektivitas Belajar Mahasiswa Berbasis Daring di Masa Pandemik Covid-19 - Juliaster Marbun, Samuel Juliardi Sinaga

DOI: https://doi.org/10.31004/basicedu.v5i5.1326

persentase dan reduksi data. Yang menjadi subjeknya Ada 200 orang yang telah memberikan respon terhadap angket yang disebarkan.

Tujuan penelitian ini adalah untuk mengetahui efektivitas penggunaan Google classroom dalam pembelajaran daring di masa pandemik Covid19. Penelitian ini dilaksanakan pada semester genap tahun pelajaran 2020/2021, melibatkan mahasiswa/i Fakultas Keguruan dan Ilmu Pendidikan (FKIP) UHN sebagai responden yang aktif mengikuti pembelajaran berbasis daring.

\section{HASIL DAN PEMBAHASAN}

\section{Analisis Data Angket}

Google classroom sebagai salah satu aplikasi berupa template formulir atau lembar kerja yang dapat dimanfaatkan oleh dosen maupun mahasiswa untuk tujuan khususnya dalam pembelajaran. Melalui aplikasi google classroom yang digunakan sebagai akses pembelajaran berbasis daring,diperoleh juga kecepatan akses informasi sehingga memudahkan dosen dalam memberikan materi kuliah yang diampuh melalui kelas-kelas virtual yang dapat diakses dimanapun dan kapanpun oleh mahasiswa yang mengikuti mata kuliah dari dosen yang bersangkutan.

\section{Tabel 1. Analisis Data Angket}

\begin{tabular}{cc}
\hline Item penilaian & Presentase \\
\hline $\begin{array}{c}\text { Kemudahan penggunaan } \\
\text { aplikasi belajar }\end{array}$ & $100 \%$ \\
\hline Kecepatan akses informasi & $90 \%$ \\
\hline Kepraktisan belajar & $95 \%$ \\
\hline Efektivitas dalam belajar & $100 \%$ \\
\hline Hasil belajar & $100 \%$ \\
\hline
\end{tabular}

Dari tabel 1 diatas, menunjukkan bagaimana kemudahan dalam menggunakan aplikasi belajar google classroom, para pengguna dengan mudah bisa mengakses aplikasi ini baik di perangkat komputer dan android. Layanan aplikasi ini tentu saja memudahkan mahasiswa dan dosen untuk menggunakan aplikasi ini selama sistem belajar berbasis daring dilakukan sesuai dengan SOP yang sudah ditetapkan. Google classroom yang sangat mudah dibuat dan diaplikasikan kedalam pembelajaran jarak jauh dimasa Pandemi Covid -19 . Kelebihan menggunakan Google Clasroom bisa memasukkan materi kuliah yang berbentuk video pembelajaran, materi maupun soal-soal yang bisa diakses dengan mudah. Kemudian melihat nilai mahasiswa dengan cepat sehingga bisa melaksanakan tindak lanjut dengan berupa remedial dan pengayaan dengan cepat dan juga data kehadiran mahasiswa bisa terpantau. Mayoritas mahasiswa yang belajar melalui aplikasi belajar Google classroom mempermudah dalam mengerjakan tugas, terampil menggunakan sarana teknologi dan informasi dan bisa dengan cepat mengetahui hasil belajarnya.

Berdasarkan hasil pada tabel 1, dapat disimpulkan bahwa secara umum mahasiswa FKIP UHN setuju bahwa aplikasi belajar berbasis daring menggunakan Google Classroom efektif diterapkan dalam pembelajaran daring selama pandemi Covid-19. Mahasiswa FKIP UHN Medan juga merasa puas mengenai efektivitas pelaksanaan pembelajaran berbasis daring dengan menggunakan aplikasi google clasroom Hasil temuan penelitian ini sejalan dengan penelitian sebelumnya, Hanifah \& Putri (2020) yang menunjukkan bahwa Google Classroom efektif digunakan sebagai media pembelajaran bagi dosen untuk menyampaikan informasi dan materi perkuliahan. Google Classroom membuat komunikasi dan interaksi mereka dengan peserta lainnya di dunia maya menjadi lebih nyaman selama kegiatan pembelajaran daring. Selain itu, hasil respon mahasiswa juga menyatakan ada kekurangan dalam menggunakan aplikasi google classroom yaitu sering terkendala dengan sinyal internet di tempat mereka tinggal dan membutuhkan biaya paket data internet yang mahal adalah tantangan tersendiri dalam pembelajaran daring di masa pandemik ini. namun dalam 
3303 Pemanfaatan Aplikasi Google Classroom dalam Meningkatkan Efektivitas Belajar Mahasiswa Berbasis Daring di Masa Pandemik Covid-19 - Juliaster Marbun, Samuel Juliardi Sinaga

DOI: https://doi.org/10.31004/basicedu.v5i5.1326

menghadapi kendala tersebut, dosen berusaha memberikan materi dan mencoba menghubungi mahasiswa melalui telepon ataupun WA untuk memastikan mahasiswanya dapat materi yang diberikan oleh dosen yang bersangkutan. Setiap dosen wajib memantau dan menghubungi semua mahasiswa yang mengikuti mata kuliah yang diampuhnya melalui grup WA bahkan menghubungi sendiri melalui telepon sebagai tanggungjawab kepada mahasiswanya agar tetap bisa mengikuti pembelajaran berbasis daring.

Hasil wawancara terhadap mahasiswa FKIP UHN Medan yang dilakukan secara daring yaitu diwawancarai melalui aplikasi Video Call via WA. Adapun wawancara yang dilakukan untuk mengetahui secara langsung dan mendengar berbagai tanggapan dari mahasiswa FKIP UHN Medan yang sedang mengikuti perkuliahan berbasis daring selama pandemik Covid-19, diperoleh hasil bahwa mahasiswa semakin mudah dalam menggunakan teknologi berbasis digital yaitu sudah bisa menggunakan berbagai aplikasi belajar digital yang mana salah satunya google classroom baik yang berupa web ataupun aplikasi adalah platform yang mudah digunakan, dosen dan mahasiswa juga bisa mengikuti pembelajaran tanpa mengenal tempat, dimanapun mereka bisa mengikuti perkuliahan sesuai dengan jadwal perkuliahan yang sudah ditentukan, mahasiswa dengan mudah menerima Materi yang dibagikan oleh dosen pengampu mata kuliah di classroom tidak membuat memori HP cepat penuh penyimpanannya berbasis cloud, aplikais ini didukung dengan berbagai fitur-fitur yang memudahkan untuk mahasiswa yang mengikuti mata kuliah, mudah melihat materi mata kuliah yang diberikan oleh dosen, dan mahasiswa juga cepat bisa mengetahui nilai pada tugas yang diberikan oleh dosen. Materi yang dibagikan di classroom dapat beragam, mulai dari file materi, video pembelajaran, dan dapat menambahkan link yang terhubung ke laman web ataupun youtube. Penggunaan aplikasi ini sangat membantu mahasiswa dalam belajar, menyimak, membaca dan mengirim tugas dari jarak jauh.

Berbagai kemudahan yang terdapat dalam sistem pembelajaran berbasis daring di masa pandemik Covid -19 ini membuat sistem pembelajaran menjadi lebih mudah dilaksanakan, sehingga memudahkan dosen dan mahasiswa dalam mengikuti kegiatan akademik setiap semesternya. Dosen dan mahasiswa di UHN pada saat ini tetap mengikuti anjuran dari pemerintah untuk mengikuti kegiatan belajar berbasis daring. Namun dibalik kemudahan pembelajaran berbasis daring ini ada kendala yang dihadapi oleh beberapa mahasiswa, adapun kendala yang dihadapi adalah sinyal yang tidak bagus di tempat mereka tinggal, keterbatasan paket data internet menjadi tantangan tersendiri dalam melaksanakan sistem pembelajaran berbasis daring. Bagi mahasiswa yang mengalami kesulitan ini dibantu oleh teman dan dosennya agar mahasiswa tersebut tidak ketinggalan materi kuliah. Dosen memberikan keringanan berupa perpanjangan waktu mengumpulkan tugas bagi mahasiswa yang sering terkendala dengan sinyal yang kurang baik didaerahnya.

Dengan demikian, menggunakan Google Classroom pembelajaran akan membuat kegiatan belajar mengajar menjadi lebih efektif, sebab dosen dan mahasiswa dapat melakukan kegiatan pembelajaran kapan saja melalui kelas daring Google Classroom (Henukh et al., 2020)

\section{KESIMPULAN}

Pada masa pandemik sekarang semua institusi pendidikan diminta untuk melakukan pencegahan penyebaran Covid-19, WHO merekomendasikan untuk menghentikan sementara kegiatan-kegiatan yang berpotensi menimbulkan kerumunan massa. Untuk itu pembelajaran konvensional yang mengumpulkan banyak siswa dalam satu ruangan perlu ditinjau ulang pelaksanaannya. Pembelajaran harus dilaksanakan dengan skenario yang mampu meminimalisir kontak fisik antara mahasiswa dengan dosen.

Salah satu media pembelajaran daring yang saat. ini sedang digunakan di Universitas HKBP Nommensen Medan adalah Google Classroom. Google Classroom adalah aplikasi khusus yang digunakan untuk pembelajaran daring yang dapat dilakukan dari jarak jauh sehingga memudahkan dosen dan mahasiswa untuk membuat, mengelompokan dan membagikan tugas, selain itu dosen dan mahasiswa bisa setiap saat 
3304 Pemanfaatan Aplikasi Google Classroom dalam Meningkatkan Efektivitas Belajar Mahasiswa Berbasis Daring di Masa Pandemik Covid-19 - Juliaster Marbun, Samuel Juliardi Sinaga DOI: https://doi.org/10.31004/basicedu.v5i5.1326

melakukan kegiatan pembelajaran melalui ruang kelas Google Classroom. Penggunaan aplikasi ini sangat membantu mahasiswa dalam belajar, menyimak, membaca dan mengirim tugas dari jarak jauh.

Berdasarkan hasil penelitian dan pembahasan yang telah dipaparkan diatas dapat disimpulkan bahwa pemanfaatan Aplikasi Belajar Google Classroom efektif diterapkan dalam pembelajaran berbasis daring selama pandemik Covid-19. Google Classroom dapat menjadi salah satu pilihan media pembelajaran alternatif bagi institusi pendidikan di Indonesia melalui media ini, Dosen dapat menampilkan kegiatan pembelajaran berbasis daring yang menarik untuk dibagikan bagi peserta didik/mahasiswa di masa pandemik Covid-19.

\section{UCAPAN TERIMA KASIH}

Terimakasih kami ucapkan kepada Tuhan Yang Maha Esa atas berkatnya sehingga kami bisa menyelesaikan artikel ini, Dekan FKIP dan jajarannya, bapak/ibu dosen dan pegawai di lingkungan FKIP UHn Medan yang telah mendukung kami mengadakan riset terkait pembelajaran daring dengan menggunakan aplikasi google classroom, kami juga mengucapkan terimakasih kepada adik-adik mahasiswa/i FKIP UHN Medan yang telah bersedia menjadi responden kami, semoga kita tetap sehat selalu dan semangat dalam belajar.

\section{DAFTAR PUSTAKA}

Ananda, R., Fadhilaturrahmi, F., \& Hanafi, I. (2021). Dampak Pandemi Covid-19 Terhadap Pembelajaran Tematik Di Sekolah Dasar. Jurnal Basicedu, 5(3), 1689-1694.

Anugrahana, Andri. (2020). Hambatan, Solusi Dan Harapan: Pembelajaran Daring Selama Masa Pandemi Covid-19 Oleh Guru Sekolah Dasar." Scholaria Jurnal Pendidikan Dan Kebudayaan ,10(3), 282-289.

D.Y. Irawati \& Jonatan.(2020). Evaluasi Kualitas Pembelajaran Online Selama Pandemi Covid-19: Studi Kasus Di Fakultas Teknik, Univ. Katolik Darma Cendika. Jurnal Rekayasa Sistem Industri.9 (2), 135144.

Dewi, W. A. F. (2020). Dampak Covid-19 Terhadap Implementasi Pembelajaran Daring Di Sekolah Dasar. Edukatif: Jurnal Ilmu Pendidikan, 2(1), 55-61.

Firman, \& Rahayu, S. (2020). Pembelajaran Online Di Tengah Pandemi Covid-19. Indonesian Journal Of Educational Science (IJES), 2(2), 81-89.

Hanifah, W., \& Putri, K. Y. S. (2020). Efektivitas Komunikasi Google Classroom Sebagai Media Pembelajaran Jarak Jauh Pada Mahasiswa Ilmu Komunikasi Universitas Negeri Jakarta Angkatan 2018. MEDIALOG: Jurnal Ilmu Komunikasi, 3(2), 24-35.

Henukh, Et.Al (2020). Implementation Of Google Classroom As Multimedia Learning. Jurnal Ilmu Pendidikan Fisika, 5(1), 38-44.

Ifthkar, Shampa. (2016). Google Classroom: What Works And How?. Journal Of Education And Social Sciences. Vol. 3.

Imania, K.A, \& S.K. Bariah (2019). Rancangan Pengembangan Instrumen Penilaian Pembelajaran Berbasis Daring. JURNAL PETIK 5(1), 31-47.

Isman, M. (2016). Pembelajaran Moda Dalam Jaringan (Moda Daring). The Progressive And Fun Education Seminar, 586-588.

Kurniasari, Asrilia, Et.Al. (2020). Analisis Efektivitas Pelaksanaan Belajar Dari Rumah (Bdr) Selama Pandemi Covid19. Jurnal Review Pendidikan Dasar. 6, (3), 246-253.

Menteri Pendidikan. (2020). Surat Edaran Nomor 4 Tahun 2020 Tentang Pelaksanaan Pendidikan Dalam Masa Darurat Coronavirus (COVID-19). 
3305 Pemanfaatan Aplikasi Google Classroom dalam Meningkatkan Efektivitas Belajar Mahasiswa Berbasis Daring di Masa Pandemik Covid-19 - Juliaster Marbun, Samuel Juliardi Sinaga DOI: https://doi.org/10.31004/basicedu.v5i5.1326

Milman, N. B. (2015). Distance Education. In International Encyclopedia Of The Social \& Behavioral Sciences: Second Edition.

N.M. Efendi. (2018). Revolusi Pembelajaran Berbasis Digital. Jurnal Pendidikan, Sosiologi Dan Antropologi (UGM), 2 (2), 173-182.

Okmawati, M. (2020). The Use Of Google Classroom During Pandemic. Journal Of English Language Teaching, 9(2), 438- 443.

Oktavian, Riskey Et Al. (2020) .Efektivitas Pembelajaran Daring Terintegrasi Di Era Pendidikan 4.0. Didaktis: Jurnal Pendidikan Dan Ilmu Pengetahuan 20(2), 129-135.

Qomariah, S., Nursobah S.L. (2019). Implementasi Pemanfaatan Google Classroom Di Era Revolusi 4.0. SINDIMAS.1(1), 227-234.

Rizqon, H.S.A. (2020) . Dampak Covid19 Pada Pendidikan Di Indonesia: Sekolah,Keterampilan, Dan Proses Pembelajaran. Jurnal Sosial\&Budaya Syar-I , 7(5), 395-402.

Sadikin, A., \& Hamidah, A.( 2020) . Pembelajaran Daring Di Tengah Wabah Covid-19. Biodik, 6(2), 214-224.

Siahaan, K. W. A., Lumbangaol, S. T. P., Marbun, J., Nainggolan, A. D., Ritonga, J. M., \& Barus, D. P. (2021). Pengaruh Model Pembelajaran Inkuiri Terbimbing Dengan Multi Representasi Terhadap Keterampilan Proses Sains Dan Penguasaan Konsep IPA. Jurnal Basicedu, 5(1), 195-205.

Sugiyono, M. (2019). Metode Penelitian Pendidikan: Pendekatan Kuantitatif, Kualitatif Dan R\&D. Bandung: Penerbit. Alfabeta.

Swita Amallia Hapsari, Heri Pamungkas. (2019). .Pemanfaatan Google Classroom Sebagai Media Pembelajaran Online Di Universitas Dian Nuswantoro. Jurnal WACANA, 18(2), 225 - 233.

Wulan, E. R.. (2015). Evaluasi Pembelajaran. Pustaka Setia: Bandung. 